\title{
Efficiency of Self-Dental Esthetic Satisfaction and The Willingness Status On Choosing Dentistry as Profession
}

\author{
Turker Yucesoy(0000-0002-1356-1574) ${ }^{\alpha}$, Enes Sengonul(0000-0001-7994-8539) ${ }^{\beta}$
}

Selcuk Dent J, 2021; 8: 379-386 (Doi: 10.15311/selcukdentj.664844)

Başvuru Tarihi: 25 Aralık 2019 Yayına Kabul Tarihi: 11 Ağustos 2020

\begin{abstract}
Efficiency of Self-Dental Esthetic Satisfaction and The Willingness Status On Choosing Dentistry as Profession

Background: While other influencing factors are well categorized on the choice of dentistry, the effect of the-self appearance and the importance of the will are not studied adequately and categorized as an influencing factor in the literature.

Methods: The structured questionnaire with 21 questions was asked to 142 dental students in Turkey. Statistical analyses were performed and the results were obtained. The questions were designed by following the factors affecting the decision of the students in choosing careers such as; willingness, economy, esthetics, past experiences with dentists, the influence of family/environment, etc.
\end{abstract}

Results: Of the individuals who wanted to become a dentist from the beginning of their education, $82.5 \%$ replied as "Dentistry has always been closer and warmer" $(p=0.002 ; p$ $<0.01$ ). Also, $70,2 \%$ of respondents' were mostly influenced by economic reasons. ( $p=0,034 ; p<0,05) .9 \%$ of the respondents replied as "I chose it because of my family/environment affected me". Almost $1 / 3$ of the students stated that the appearance of the teeth influenced their choice of dentistry but the effect was statistically significant.

Conclusion: This is the first study in the literature that reports the state of dental self-esthetics might be considered as an influencing factor in choosing dentistry. The willingness of the students' in the choice of dentistry was also highly statistically significant whereas the economical considerations were the most ranked factor among the other influencing factors in students' career plans.

\section{KEYWORDS}

Advanced dental education, Assessment, Esthetic dentistry, Predental, Undergraduate dental education

Choice of a profession is a very complicated issue as it is one of the most important decisions of a person's life, is associated with many difficulties and sensitivities. ${ }^{1,2}$ Many factors such as an individual's future dreams, interests, wishes, physical and psychological characteristics, academic success, friends' perceptions, family's expectations, socioeconomic status and economic concerns associated with the profession affect the choice of occupation. ${ }^{1,3}$

When it comes to the dentistry, it is reported that the

\section{öz}

Diş Hekimliği Mesleği Seçiminde Öz Dental Estetik ve İsteklilik Durumunun Etkinliği

Amaç: Bu çalışmada, Türkiye'de eğitim gören diş hekimliği öğrencilerinin meslek seçiminde kişinin kendi dental durumu ve isteklilik gibi kişisel faktörlerin etkinliğinin belirlenmesi amaçlanmıştır.

Gereç ve Yöntemler: 142 diş hekimliği öğrencisine 21 sorudan oluşan yapılandırılmış anket formu sorulmuştur. Sorular, öğrencilerin kariyer seçiminde kararlarını etkileyen faktörler izlenerek tasarlanmıştır; isteklilik, ekonomi, estetik, diş hekimleriyle geçmiş deneyimler, ailenin/çevrenin etkisi vb. sorular teker teker ve birbirleriyle ilişkisine göre değerlendirilmiştir. İstatistiksel analizler yapılmış olup istatistiksel olarak anlamlı sonuçlar elde edilmiştir.

Bulgular: Eğitim başlangııından itibaren diş hekimi olmak isteyenlerin \%82.5' "Diş Hekimliği her zaman daha yakın ve daha sıcak gelmiștir" olarak yanıtlamışı ır $(p=0.002 ; p<0.01)$. Ayrıca, ankete katılanların \% 70,2' si çoğunlukla ekonomik nedenlerden etkilenmiștir. ( $p=0,034 ; p<0,05)$. Ankete katılanların\% 9'u "Ailem / çevremden etkilendiğim için seçtim" diye cevap vermiştir. Öğrencilerin yaklaşık 1/3'ü kendi dişlerin görünümünün diş hekimliği seçimini etkilediğini bildirmiştir ancak etkinin istatistiksel olarak anlamlı olduğunu tespit edilmiştir.

Sonuç: Bu çalışma, literatürde öz dişsel durumun değerlendirildiği ve diş hekimliği seçiminde etkili bir faktör olarak düşünüldüğü ilk çalışmadır. Ayrıca çalışmada öğrencilerin bu tercihi yapmalarındaki diğer tüm etkenler de incelenmiş olup sonuçları rapor edilmiştir. Öğrencilerin diş hekimliği seçimindeki istekliliği de istatistiksel olarak anlamlı sonuç verirken, ekonomik düşünceler öğrencilerin kariyer planlarında diğer etkileyen faktörler arasında en üst sırada yer almıştır.

\section{ANAHTAR KELIMELER}

Diş hekimliği, Eğitim, Kariyer seçimi, Dental estetik, Meslek

perceiving of student's factors in choosing faculty of dentistry can support effective recruitment materials. ${ }^{4}$ It has been also suggested that more information about the students' reasons for choosing dentistry may help the better interaction between student and teacher. ${ }^{5}$ For this reason, several investigations on factors and motivations in choosing dentistry have been performed in different countries. $^{6-12}$ These studies revealed that students who chose dentistry as a career, are influenced by various factors such as financial gain, the recommendation of

\footnotetext{
${ }^{\alpha}$ Bezmialem Vakif University Dentistry Faculty Oral and Maxillofacial Surgery Department, İstanbul, Turkey

$\beta$ Private Dental Clinic, Istanbul, Turkey
} 
family or friends and dental history. ${ }^{13,14}$

The first goal of this study was to identify the motivation for choosing dentistry as a career among Turkish dental students at Bezmialem Vakif University. The second goal was to investigate the effect of dental appearance and the will on choice of dentistry before dentistry choice in Turkish dental student.

\section{MATERIALS AND METHODS}

\section{Ethical Statements}

All protocols of this study were reviewed and approved by the Bezmialem Vakıf University Local Ethics Committee.

\section{Study Designation}

An anonymous questionnaire, consisting of 21 questions about students' motivation for choosing dentistry, was administered to 142 dental students at the Faculty of Dentistry of the Bezmialem Vakif University in Turkey. The questions were designed by following the factors affecting the decision of the student's in choosing career such as; will, economy, esthetics, past experiences with dentists, the influence of family/environment, etc. Personal information (such as name, surname, date of birth, etc.) was not asked to answer the questionnaire more comfortably. The study was conducted during the 2019-2020 academic year. Students from the first through fifth years were asked to participate. A structured questionnaire was prepared, and pre-testing was done on a study group to identify necessary modifications and eliminate unclear points. Before the study, the students were informed about the content and were assured of the confidentiality of the research. The completion of the questionnaire they were given the questionnaire by each student was taken as a form of individual consent to participate in the study.

\section{Statistical Evaluation}

The majority of the questions were standardized. Some questions were written as a scale, and the students were allowed to give only one answer to each question. Statistical analysis was performed using the NCSS (Number Cruncher Statistical System) 2007 (Kaysville, Utah, USA). During the evaluation of the data, apart from descriptive statistical methods (mean, standard deviation, frequency distribution), chi-square and Fisher Freeman Halton reality tests were used to compare multiple qualitative data. Significance was evaluated at least $p<0.05$. It was also evaluated whether these tests and the answers given to the questionnaire were compatible with each other.

\section{RESULTS}

This study was performed with 142 individuals and 21 questions were asked to each one. The answers were recorded, examined and compared with each other, respectively. Some of the statistically significant or insignificant but interesting results are reported in this section. The outcomes are reported under the subtitles as; "Importance of The Will" and "Esthetic Considerations and Regret Status".

"IMPORTANCE OF WILL"

\section{Question 1: "Did you choose dentistry willingly?"}

$42 \%$ of respondents $(n=59)$ replied as "I wanted to be a dentist from the beginning of my education". 9\% $(n=13)$ replied as "I chose it because of my family/environment affected me", $23 \%(n=33)$ replied "I chose it because it was from a prestigious profession group", $10 \%(n=14)$ replied "Dentist who is from my family/ environment affected me" The rate of those who replied, "Not one of them" was found to be $16 \%(n=23)$. (Graphic 1-A)

Question 2: "Would you like to choose other health sciences departments?"

$60 \%$ of those respondents $(n=86)$ replied as "Dentistry had always been warmer and closer", and $20 \%(n=28)$ replied as "I wanted to study medical school" whereas $9 \%(n=13)$ replied as "I have no idea", $6 \%(n=8)$ as "I would like to be a pharmacist" and $5 \%(n=7)$ replied as "I would like to study in other health sciences faculties." such as nursery, physiotherapy, etc. Graphic 1-B)

Of the individuals who replied as "I wanted to become a dentist from the beginning of my education", $82.5 \%$ of them replied as "Dentistry has always been closer and warmer". $(p=0.002 ; p<0.01)$. (Table 1)

Table 1.

\section{Evaluation of the Choice of Other Health Sciences According to the Willing Choosing Dentistry}

\begin{tabular}{|c|c|c|c|c|c|c|c|}
\hline \multicolumn{8}{|c|}{ Did you choose dentistry willingly? } \\
\hline & & $1(n=57)$ & $2(n=11)$ & $3(n=33)$ & $4(n=18)$ & $5(n=24)$ & P \\
\hline & & $n(\%)$ & $\mathrm{n}(\%)$ & $\mathrm{n}(\%)$ & $\mathrm{n}(\%)$ & $n(\%)$ & $0,002^{\star *}$ \\
\hline \multirow{5}{*}{ 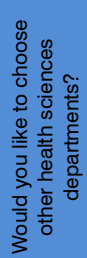 } & 1 & $5(8,8)$ & $1(9,1)$ & $10(30,3)$ & $4(22,2)$ & $4(16,6)$ & \\
\hline & 2 & $47(82,5)$ & $5(45,5)$ & $19(57,5)$ & $8(44,4)$ & $13(54,2)$ & \\
\hline & 3 & $0(0)$ & $1(9,1)$ & $2(6,1)$ & $0(0)$ & $3(12,5)$ & \\
\hline & 4 & $2(3,5)$ & $1(9,1)$ & $0(0)$ & $2(11,2)$ & $1(4,2)$ & \\
\hline & 5 & $3(5,2)$ & $3(27,2)$ & $2(6,1)$ & $4(22,2)$ & $3(12,5)$ & \\
\hline
\end{tabular}


Question 3: "Would you like to choose other professional groups?"

$56 \%(n=80)$ of respondents replied as "I am happy with dentistry". $17 \%(n=24)$ of the individuals replied as "I would like to prefer fine arts" whereas $13 \%$ $(n=19)$ replied as "I prefer engineering sciences", 9\% $(n=12)$ answered "Other" and $5 \%(n=7)$ replied as "I would prefer social sciences". (Graphic 1-C)

Question 4: "What are your hobbies?"

According to the results of this question, all respondents stated that they have hobbies and most of them are performed by the hands and additionally they are mostly art-related. (Graphic 1-D)

Question 5: "Did you consider economic reasons when choosing dentistry?"

In total of $45 \%$ of the respondents replied as "I agree" $(30 \%(n=43))$ and "I absolutely agree" $(15 \%(n=21))$ $(p=0,034 ; p<0,05)$. (Table 2).

Table 2.

Evaluation of the Consideration of Economic Reasons When Willingly Choosing Dentistry

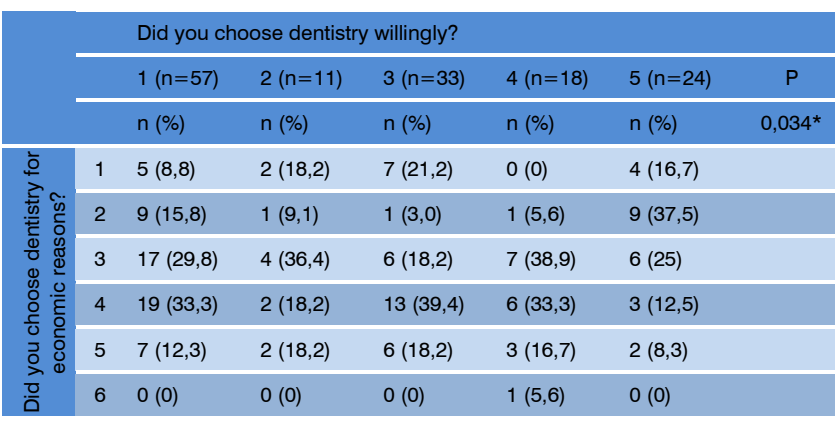

Fisher Freeman Halton Test ${ }^{*} p<0,05$

Moreover, $27 \%(n=39)$ replied as "Somewhat agree". In contrast, in total of $27 \%$ of the respondents answered "Do not agree" $(15 \% \quad(n=21))$ and "Absolutely do not agree" (12\% $(n=18))$ answered whereas $1 \%(n=1)$ replied as "No idea". (Graphic 1-E) Eventually, \%72 of individuals of this study "considered" economic reasons for choosing dentistry.

Question 6: "When choosing dentistry, was it effective to have a familiar dentist in your family / environment?"

$33 \%(n=47)$ of respondents replied as "I did not know any dentist" and $33 \%(n=46)$ of the individuals replied as "I knew dentist and they affected me" whereas $23 \%(n=36)$ replied as "I knew dentist and they did not affect me", 11\% $(n=16)$ answered as "My dentist affected me". (Graphic 1-F). Eventually, \%44 of individuals of this study could be "considered" as they were affected by the previous dentist experiences for choosing dentistry.

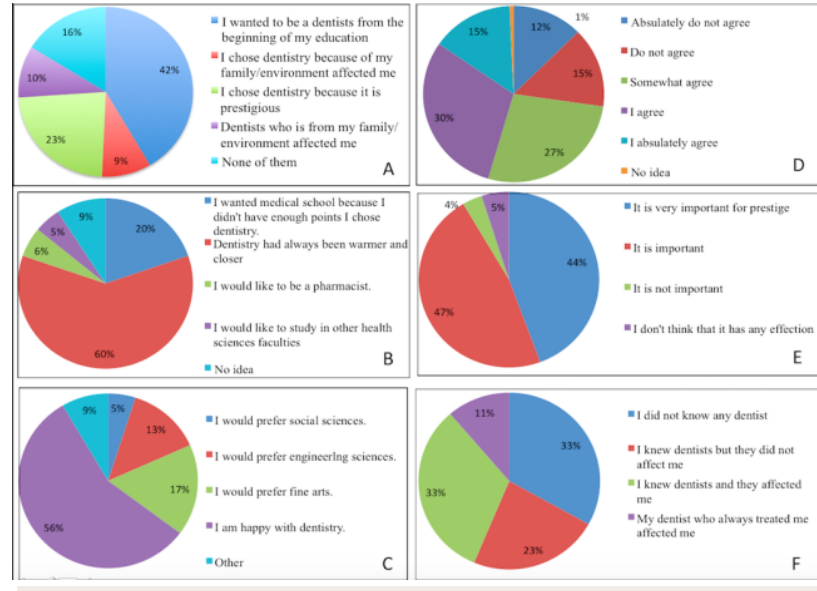

Graphic 1

Graphic A: Results of "Did you choose dentistry willingly?" question. Graphic B: Results of "Would you like to choose other health sciences departments?" question. Graphic C: Results of "Would you like to choose other professional groups?" question. Graphic D: Results of "What are your hobbies?" question. Graphic E: Results of "Did you consider economic reasons when choosing dentistry?" question. Graphic F: Results of "When choosing dentistry, was it effective to have a familiar dentist in your family/environment?" question.

\section{ESTHETIC CONSIDERATIONS AND REGRET} STATUS

Question 7: "Did finding your teeth beautiful or ugly have any effect on choosing dentistry profession?"

$9 \%(n=13)$ of respondents replied as "I agree". And also, $6 \%(n=8)$ of the individuals replied as "I absolutely agree" whereas $16 \%(n=23)$ replied as "Somewhat agree", 39\% $(n=55)$ answered "Do not agree", $27 \% \quad(n=39)$ answered "Absolutely do not agree", and $3 \%(n=4)$ replied as "No idea". (Graphic $2-\mathrm{G})$.

Question 8: "Do you think it is important to have your teeth crossed or aligned properly when communicating with patients as a dentist?"

$44 \%(n=63)$ of respondents replied as "It is very important for prestige". Additionally, $47 \%(n=67)$ of the individuals replied as "It is important " whereas $5 \%(n=7)$ replied as "It is not important" and $4 \%$ $(n=5)$ replied as " I don't think that it has any effection ". (Graphic 2-H).

Question 9: "Did you receive an orthodontic treatment?"

$43 \%$ of the 142 respondents $(n=61)$ received or are currently receiving orthodontic treatment. (Graphic 2-I).

\section{Question 10: "Do you like the way you smile?"}

$49 \%(n=67)$ of respondents replied as "I like it". Moreover, $27 \%(n=37)$ of the individuals replied as "Somewhat" whereas $14 \%(n=19)$ replied as "I like it very much", $7 \%(n=9)$ answered "I do not like", 3\% $(n=4)$ answered "I do not like it at all", and 0\% $(n=0)$ replied as "No idea". (Graphic 2-J). 


\section{Question 11: "Do you regret choosing dentistry?"}

$48 \%(n=63)$ of respondents replied as "I do not regret, I would choose it even today". $32 \%(n=41)$ of the individuals replied as "My love for my profession increases as time goes on" whereas $16 \%(n=21)$ replied as "My love for my profession decreases as time goes on", $4 \%(n=5)$ replied as "I regret" and $8 \%$ $(n=12)$ replied as "I'm very regretful" (Graphic 2-K).

Question 12: "Were there any individuals with serious dental problems in your family or environment?"

$32 \%(n=46)$ of respondents replied as "I had relatives with a severe toothache". And also, $27 \%(n=38)$ of the individuals replied as "I had relatives with pain in the jaw joint." whereas $13 \%(n=20)$ replied as "I often had relatives with large/small oral lesions." $9 \%(n=12)$ answered " I had relatives with severe dental abscesses.", 9\% $(n=12)$ answered "I didn't have any dental problems around me.", and $6 \%(n=9)$ replied as "I had relatives who had contraindicated dental procedures because of systemic disorders.", $4 \%(n=5)$ answered as "I had relatives with cleft lip/palate" (Graphic 2-L).

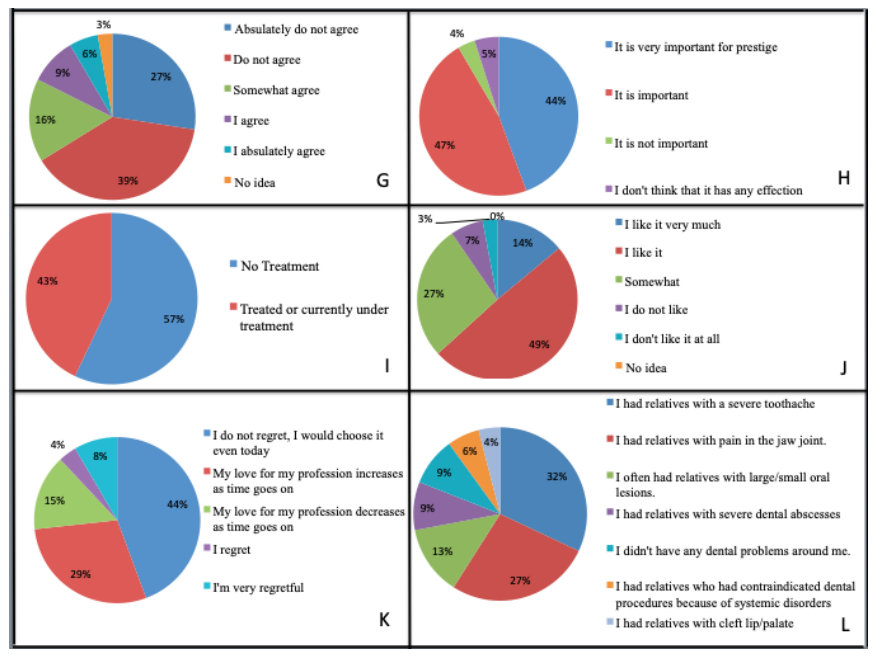

Graphic 2

Graphic G: Results of "Did finding your teeth beautiful or ugly have any effect on choosing dentistry profession?" question. Graphic H: Results of "Do you think it is important to have your teeth crossed or aligned properly when communicating with patients as a dentist?" question. Graphic I: Results of "Did you receive orthodontic treatment?" question. Graphic J: Results of "Do you like the way you smile?" question. Graphic K: Results of "Do you regret choosing dentistry?" question. Graphic L: Results of "Were there any individuals with serious dental problems in your family or environment?" question.

\section{DISCUSSION}

Numbers of influencing factors affect the potential students on making a decision and choosing the professional career. While choosing the profession, the most influenced factors of the students' are the will and financial ability (or inability) for the period of training, strengths and weaknesses, specific personal interests and desires, prestigious factors, working conditions, financial expectations and the availability and attractiveness of alternative occupations. ${ }^{1,15}$

\section{THE WILL}

The motivation of the students' profession choice can not be evaluated separately from the specific social, economic and political environment. Additionally, it depends on the developments in the profession, health policy and increased demands of society. ${ }^{7}$ However, the dentistry is a quite stressful as a profession for the individuals. ${ }^{16}$ Therefore, we considered that the will should be highly associated with the success and regret status for dentistry as well as the self-motivation takes an important role in one's profession selection.

In the literature, Avramova et al indicated that the majority of the students $(73 \%)$ were self-motivated to study dentistry. ${ }^{17}$. Similar results were reported by Marino et al revealed that $85.3 \%$ of the students were mostly self-motivated to pursue a dental career ${ }^{18}$. In Sweden, one study reported that $70 \%$ of Swedish students were content with their dental school life, where only $32 \%$ of Japanese students were satisfied ${ }^{19}$. On the other hand, one of the studies from Turkey revealed that only $12 \%$ of the students said that they are satisfied with their dental school life and $30.1 \%$ of the students want to change their career. ${ }^{20}$. Considering this study was performed in a state university, another important study in a private university in Turkey reported a first choice of dentistry faculty with a score of $58.5 \%$.

Consistent with the literature, $42 \%$ of respondents replied as "I wanted to be a dentist from the beginning of my education" and there was a highly statistically significant difference in the preference of other health sciences departments according to the willingly choose of dentistry in the present study of the individuals who wanted to become a dentist from the beginning of their education, $82.5 \%$ replied as "Dentistry has always been closer and warmer". $(p=0.002 ; p<0.01)$. (Table 1) Therefore, we concluded that will and choice of the dentistry as a profession is highly related in the present study performed in a private dentistry faculty in Turkey.

Additionally, another outcome of our study revealed that $20 \%$ of respondents replied as "I wanted to study medical school". Although our study outcomes reported that $60 \%$ of the individuals were happy with the dentistry choice, due to a study performed in India, Patel et al stated that most of the students choose dentistry as an alternative to medicine. ${ }^{21}$ In the literature, some of the studies also supported that outcome with the high percentages (53-66\%) of students wished to have a career in medicine as a first choice. ${ }^{1,22}$ On the other hand, different studies reported that dentistry was generally the first choice of the students who are currently being educated in the dentistry faculties with different percentages; Çapan et al; $43.2 \%^{20}$, Tanalp et al,;58,5 23 Bourgzui et al; $36 \%^{24}$, Skelly et al; $33 \%{ }^{25}$, Jover et al, ; $41 \%^{12}$ and Al-Bitar et al, $; 46 \%{ }^{22}$ as their first choice. 


\section{FAMILY/ENVIRONMENT INFLUENCE}

Family or environment is not negligible on one's choice of profession. Therefore, those results tend to be affected by the difference in cultures. For example, the students in Japan and the Asian countries could be highly influenced by their family whereas the students in western cultures are not influenced as well as the eastern cultures on choosing dentistry as an occupation. ${ }^{19,26}$

In the literature, it could be easily concluded that students in Turkey were particularly influenced by their families/environment $61.4 \%$ and $92,5 \%$, respectively. ${ }^{20,23}$ However, our results revealed that $9 \%$ of the respondents replied as "I chose it because of my family/environment affected me", which is extremely lower than the other studies performed in Turkey and all around the world. It may be concluded that the lower results would be because we asked the respondents to answer only one option in this question; "Did you choose dentistry willingly?" Because as it was reported earlier, most individuals do not hold to one crucial justification on choosing the profession. ${ }^{5}$ In the same question $10 \%$ of the respondents replied as "Dentist who is from my family/ environment affected me", however ,\%44 of individuals of this study could be "considered" as they were affected by the previous dentists experiences for choosing dentistry when another question ("When choosing dentistry, was it effective to have a familiar dentist in your family/environment?") is asked. (Graphic 1-F).

\section{ECONOMICAL ASPECT:}

Independent of they were performed in developed countries, it is likely to consider that "economical expectations" is one of the most crucial outcomes from the studies on choosing dentistry. In contrast with that "belief", Rad et al stated that the financial appeal of the dental profession had declined in Iran when compared with other factors. They also reported that the outcome does not necessarily reflect a decrease in dentists' income; rather, it might reflect a higher income in other professions and the effect of income should not be overlooked with choosing the dental profession. ${ }^{27}$

On the other hand, in a study in the USA, Hawley et al reported that the perception of dentistry as being "high in income potential with flexible hours and familyfriendly opportunities" may be associated to the appearance of the dentistry. ${ }^{13}$ Along with that, some studies reported that "financial awards" of the profession were among the highest-ranked reasons for the selection of dentistry for both genders. ${ }^{1,20,23}$ Furthermore, Hallanway et al. revealed a relatively higher percentage of respondents in his study agreed to a considerable or great extent with "high income" and "high professional status" compared with other motivating factors. ${ }^{28}$ Furthermore, in one of the studies that performed among dentistry students from Turkey, Çapan et al. concluded that the financial gain $(87,2 \%)$ is the most important criteria in students' career plans 20.

Consistently with the literature, we report that the most significant outcomes are provided from "the will in choosing dentistry" (Graphic 1-A) and "the economical considerations" (Graphic 1-E) among the dentistry students in Bezmialem Vakif University, Turkey. There is a statistically significant difference in the choice of dentistry by considering economic reasons. $45.6 \%$ of the individuals who wanted to be a dentist from the beginning of their education, replied as "I absolutely agree" and "I agree" and 24,6\% replied as "Somewhat agree" Eventually it could be concluded that of $70,2 \%$ of respondents' was affected by economical reasons. (Table 2)

\section{PRESTIGE}

Another important parameter for students on choosing dentistry is "prestige". In most recent studies, it is reported that prestigious reasons take an important role in profession choosing such as $85,2 \%$ of respondents in Turkey ${ }^{20}$ whereas another study from India reported that the prestige of the profession is the most important factor. ${ }^{29}$ According to a study from Bulgaria, the majority of respondents $(73 \%)$ believed that dentistry was a prestigious occupation. ${ }^{17} 94.2 \%$ of dentistry and $75 \%$ of medical students in the present study believed that winning a high social status was the most important factor in their choice of majors among Iranian students ${ }^{27}$ In contrast, $6 \%$ of dental students in the $\mathrm{UK}^{9}$, in the $\mathrm{US}^{30}$ and $0.9 \%$ in Denmark $^{31}$ agreed with the statement that a prestigious social standing was the motivation for their choice of career.

In our present study, $23 \%$ of respondents replied as "I chose it because it was from a prestigious profession group". But, we believe that the "rate of prestige" would be higher if we let our respondents check more than one option. Because when we asked "Do you think it is important to have your teeth crossed or aligned properly when communicating with patients as a dentist?" $91 \%$ of the respondents checked that it is important and $\% 44$ of them replied as "It is very important for prestige". (Graphic H).

\section{ESTHETICS AND REGRET STATUS}

Oral health includes its influence on the subject's social life and dentofacial self-confidence. In their study, Afroz et al concluded that self-perceived image of dental esthetics can remarkably affect an individual's social and psychological well-being 
which is reflected in their behavior and can affect their self-confidence. ${ }^{32}$ As the major reasons for choosing dentistry was discussed in the literature and our study so far, here we report that this is the first study in the literature in which the "esthetic considerations" is searched and evaluated in the dentistry students. Therefore, we asked several questions to determine if there was any influence of self-esthetics on choosing the profession.

According to our study results, even though there was no statistically significant difference for this question, almost $1 / 3$ of the individuals of this study revealed that previous esthetic considerations affected their preferences on the profession. (Graphic 2-G) Also, when it is asked "Do you like the way you smile?" only almost \%10 of individuals of this study it answered that they don't like their smile. (Graphic 2-J) Moreover, even if they stated that the appearances of their smile; even so $43 \%$ of the 142 respondents $(n=61)$ received or are currently receiving orthodontic treatment to have a better smile and dental health. (Graphic 2-I).

In the results, it is reported that $91 \%$ of the respondents thought that the appearance of a smile of a dentist is important. Additionally, $90 \%$ of them like the way they smile. So, these highly correlated outcomes may be subconsciously associated with choosing dentistry as a profession. Because this is the first study, it is very difficult to discuss with the literature. Hence, further studies are required to determine the effect of the subconscious and the number of respondents should be higher to have more significant outcomes.

When it comes to regret status, it is reported that the percentage of students who would prefer dentistry again was decreased in higher classes. ${ }^{20}$ Consistent with this study, it is reported that the percentage of fifthyear students was the lowest-ranked. This result can be explained by increasing theoretical and practical density and stress, especially in the fourth and fifth years as Froeschle et al revealed dental education is very stressful. ${ }^{16}$ In contrast, even though we did not make a specific year of the education-based study, we report that \% 73 of individuals are considered as "not regretful" for choosing dentistry in the present study. (Graphic 2K) Moreover and surprisingly, there was a highly statistically significant difference in the state of regret from the choice of dentistry according to the satisfaction with the smile. $(p=0,019 ; p<0,05)$. (Table 3) 97 out of 127 individual who likes their smile, do not feel regret for choosing this profession. We believe that this outcome is very crucial and recommend to the academicians for this parameter to ask in their future studies and oneself for the students to keep in mind while choosing the dentistry.
Table 3.

Evaluation of Regret Status of Choosing Dentistry Among The Individuals Who Likes The Way They Smile

\begin{tabular}{|c|c|c|c|c|c|c|c|c|}
\hline & & \multicolumn{6}{|c|}{ Do you like the way you smile? } & \multirow{2}{*}{$\begin{array}{l}P \\
0,019^{\prime}\end{array}$} \\
\hline & & 1 & 2 & 3 & 4 & 5 & 6 & \\
\hline & & $(n=18)$ & $(n=70)$ & $(n=39)$ & $(n=10)$ & $(n=3)$ & $(n=3)$ & \\
\hline & & $n(\%)$ & $n(\%)$ & $n(\%)$ & $n(\%)$ & $n(\%)$ & $n(\%)$ & \\
\hline \multirow{5}{*}{ 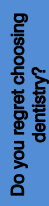 } & 1 & $6(33,3)$ & $36(51,4)$ & $19(48,7)$ & $5(50)$ & $0(0)$ & $0(0)$ & \\
\hline & 2 & $6(33,3)$ & $18(25,7)$ & $12(30,8)$ & $3(30)$ & $1(33,3)$ & $2(66,7)$ & \\
\hline & 3 & $5(27,8)$ & $8(11,4)$ & $2(5,1)$ & $1(10)$ & $1(33,3)$ & $1(33,3)$ & \\
\hline & 4 & $1(5,6)$ & $2(2,9)$ & $0(0)$ & $1(10)$ & $0(0)$ & $0(0)$ & \\
\hline & 5 & 0 (0) & $6(8,6)$ & $6(15,4)$ & $0(0)$ & $1(33,3)$ & $0(0)$ & \\
\hline
\end{tabular}

\section{LIMITATIONS OF THE STUDY}

Limitations of the present study are the lack of adequate questioning the ease of employment and flexible working hours and altruism. Also, the outcomes of the study were not evaluated according to gender and socio-economical status of the students' families.

\section{CONCLUSIONS}

- The will of the students' in the choice of dentistry was highly statistically significant in the present study but the economical considerations were the most ranked factor among the other influencing factors in students' career plans.

- Even though the preference of a medical faculty as the first choice is an important factor in choosing dentistry, only $20 \%$ of the students stated that the medicine was their first choice, which revealed similar outcomes with fine arts preference.

- This is the first study in the literature that reports that the state of the esthetics of students' should be searched and considered as an influencing factor on choosing dentistry as a profession before they make the final decision. Because there was a highly statistically significant difference in regret status from the choice of dentistry according to the satisfaction with the way they smile.

- Finally, the dentistry faculties of the universities and undergraduate advisors should understand the influencing factors and perceptions of the students better and prepare specified educational activities, such as summer dental program for the students before they applied to universities.

\section{ACKNOWLEDGEMENT}

We would like to thank to Assist. Prof. Dr. E. Dilara Şeker for her cooperation and help for the present study. 


\section{REFERENCES}

1. Scarbecz M, Ross JA. Gender differences in first-year dental students' motivation to attend dental school. Journal of dental education. 2002;66(8):952-961.

2. Rice C, Hayden W, Glaros A, Thein D. Career changers: dentists who choose to leave private practice. The Journal of the American College of Dentists. 1997;64(1):20-26.

3. Gati I, Osipow SH, Givon M. Gender differences in career decision making: The content and structure of preferences. Journal of Counseling Psychology. 1995;42(2):204.

4. Abbott BJ, Wege W, Volkmann K, Forde E. Dental student recruitment. Journal of dental education. 1984;48(12):645-648.

5. Zadik D, Gilad R, Peretz B. Choice of dentistry as a career and perception of the profession. Journal of dental education 1997; 813-816. Available at. Accessed 10,61 .

6. Gerbert B, Bernzweig J, Bleecker T, Bader J, Miyasaki C. How dentists see themselves, their profession, the public. The Journal of the American Dental Association. 1992;123(12):72-78.

7. Brand A, Chikte U. Student attitudes to dentistry in South African dental schools. The Journal of the Dental Association of South Africa $=$ Die Tydskrif van die Tandheelkundige Vereniging van Suid-Afrika. 1997;52(12):713-720.

8. Brand A, Chikte U, Thomas C. Choosing Dentistry as a career-A profile of entering students (1992) to the University of Sydney, Australia. Australian dental journal. 1996;41(3):198-205.

9. Crossley ML, Mubarik A. A comparative investigation of dental and medical student's motivation towards career choice. British dental journal. 2002;193(8):471.

10. Whittaker D. Reasons for choice of dentistry as a career in applicants to a British dental school. British dental journal. 1984;156(1):23.

11. Hallissey J, Hannigan A, Ray N. Reasons for choosing dentistry as a career-a survey of dental students attending a dental school in Ireland during 1998-99. European Journal of Dental Education. 2000;4(2):7781.

12.Jover M, Doudoux D, Deveaux E. Representations of the dental surgery profession and the motivations given by second-year French students for applying for dental surgery. European Journal of Dental Education. 2006;10(1):2-9.

13. Hawley NJ, Ditmyer MM, Sandoval VA. Predental students' attitudes toward and perceptions of the dental profession. Journal of Dental Education. 2008;72(12):1458-1464.

14. McHugh S, Corrigan M, Sheikh A, Lehane E, Broe P, Hill A. A study of the factors influencing school-going students considering medical careers. The surgeon. 2011;9(4):191-194.
15. Kaldenberg DO, Becker BW, Zvonkovic A. Work and commitment among young professionals: A study of male and female dentists. Human Relations. 1995;48(11):1355-1377.

16. Froeschle ML, Sinkford JC. Full-time dental faculty perceptions of satisfaction with the academic work environment. Journal of Dental Education. 2009;73(10):1153-1170.

17.Avramova N, Yaneva K, Bonev B. First-year dental students' motivation and attitudes for choosing the dental profession. Acta medica academica. 2014;43(2):113.

18. Mariño R, Au-Yeung W, Habibi E, Morgan M. Sociodemographic profile and career decisions of Australian oral health profession students. Journal of dental education. 2012;76(9):12411249.

19. Karibe H, Kawakami T, Suzuki A, et al. Career choice and attitudes towards dental education amongst dental students in Japan and Sweden. European Journal of Dental Education. 2009;13(2):80-86.

20. Çapan BŞ, Akyüz S, Bahcecik N, Yarat A, Girgin F. Factors Influencing Career Choices of Dental Students in a State University in Turkey. Clinical and Experimental Health Sciences. 2018;8(4):228-236.

21.Patel D, Saiyed MH. Reasons for choosing dentistry as a career: a study of first year dental students, India. Journal of International Oral Health. 2009;1(1).

22. Al-Bitar Z, Sonbol H, Al-Omari I. Reasons for choosing dentistry as a career by Arab dental students. European Journal of Dental Education. 2008;12(4):247-251.

23.Tanalp J, Ilguy D, Dikbas I, Oktay I. Demographic profile and future expectations of students enrolled in a Turkish private dental school. Journal of dental education. 2012;76(6):800-809.

24.Bourzgui F, Abidine Z, Serhier Z, Diouny S, Othmani MB. Motivational factors influencing career choices of Moroccan dental students. Profession. 2014;170:22.26.

25. Skelly AM, Fleming GJ. Perceptions of a dental career among successful applicants for dentistry compared with those of fifth-year dental students. Primary Dental Care. 2002;9(2):41-46.

26. Gallagher J, Clarke W, Wilson N. Understanding the motivation: a qualitative study of dental students' choice of professional career. European Journal of Dental Education. 2008;12(2):89-98. 
27.Rad FH, Ghaffari T, Hoshyar E. Motivations for choosing field of study among medical and dental students of Tabriz University of Medical Sciences, Tabriz, Iran. Research and Development in Medical Education. 2014;3(1):25.

28. Halawany HS. Career motivations, perceptions of the future of dentistry and preferred dental specialties among saudi dental students. The open dentistry journal. 2014; 8:129.

29.AnbuSelvan GPJ, Gokulnathan S, PrabuRajan V, RajaRaman G, Kumar SS, Thagavelu A. A study among dental students regarding the factors influenced dental students to choose dentistry as career. Journal of pharmacy \& bioallied sciences. 2013;5(Suppl 1): S36.

30. Rice CD, Glaros AG, Shouman R, Hlavacek M. Career choice and occupational perception in accelerated option and traditional dental students. Journal of dental education. 1999;63(4):354-358.

31.Gietzelt D. Social profile of first-year dentistry students at the University of Sydney. Australian dental journal. 1997;42(4):259-266.

32.Afroz S, Rathi S, Rajput G, Rahman SA. Dental esthetics and its impact on psycho-social wellbeing and dental self confidence: A campus based survey of North Indian University students. The Journal of Indian Prosthodontic Society. 2013;13(4):455-460.

Corresponding Author:

Turker YUCESOY

Bezmialem Vakif University Faculty of Dentistry

Department of Oral and Maxillofacial Surgery,

İstanbul, Turkey

Phone : +90 2125232288 (ext:1139)

E-mail : dt.yucesoy@hotmail.com 